Board of Governors of the Federal Reserve System

International Finance Discussion Papers

Number 748

July 2002

This revision: March 2005

\title{
OPTIMAL MONETARY POLICY WITH DURABLE CONSUMPTION GOODS
}

(formerly titled "Optimal Monetary Policy with Durable and Non-durable Goods")

Christopher J. Erceg and Andrew T. Levin

NOTE: International Finance Discussion Papers are preliminary material circulated to stimulate discussion and critical comment. References to International Finance Discussion Papers (other than an acknowledgment that the writer has had access to unpublished material) should be cleared with the author or authors. Recent IFDPs are available on the Web at www.federalreserve.gov/pubs/ifdp. The views in this paper are solely the responsibility of the authors and should not be interpreted as reflecting the views of the Board of Governors of the Federal Reserve System or any other person associated with the Federal Reserve System. 


\title{
Optimal Monetary Policy with Durable Consumption Goods
}

\begin{abstract}
We document that the durable goods sector is much more interest-sensitive than the non-durables sector, and then investigate the implications of these sectoral differences for monetary policy. We formulate a twosector general equilibrium model that is calibrated both to match the sectoral responses to a monetary shock derived from our empirical VAR, and to imply an empirically realistic deg ree of sectoral output volatility and comovement. While the social welfare function involves sector-specific output gaps and inflation rates, the performance of the optimal policy rule can be closely approximated by a simple rule that targets a weighted average of aggregate wage and price inflation. In contrast, a rule that stabilizes a more narrow measure of final goods price inflation performs poorly in terms of social welfare.

JEL classification: E31; E32; E52.

Keywords: Sectoral disaggregation, DGE models, VAR analysis.
\end{abstract}

Christopher Erceg* and Andrew Levin

Federal Reserve Board

20th and C Street, N.W.

Washington, D.C. 20551

* Corresponding author

Telephone: 202-452-2575

FAX: 202-872-4926

Email: Christopher.Erceg@frb.gov 


\section{Introduction*}

In past decades, macroeconomists were acutely aware of the extent to which monetary policy can have disparate effects across the various sectors of the economy. ${ }^{1}$ Such differences were particularly evident during the U.S. disinflationary episode of 1981-82, when high real interest rates induced dramatic declines in auto sales and residential construction. Nevertheless, recent empirical research has mainly focused on the aggregate effects of monetary policy shocks, while normative studies of policy rules have typically utilized models consisting of a single productive sector. $^{2}$

The objective of this paper is to assess the implications of sectoral heterogeneity for the design of welfare-maximizing monetary policy rules. As a prelude to the normative analysis, we document that the durable consumption goods sector is much more interest-sensitive than the rest of the economy. In particular, we perform vector autoregression (VAR) analysis of quarterly U.S. national accounts data, disaggregated into spending and prices for our broad measure of consumer durables (which includes residential investment) and for all other items. Using fairly standard identifying assumptions, we find that a monetary policy innovation has a peak impact on consumer durables spending that is several times larger than the impact on other expenditures.

We proceed to formulate a dynamic general equilibrium model with two sectors that produce durable and non-durable consumption goods, respectively. The model incorporates nominal inertia in the form of fixed-duration staggered wage and price contracts in each sector. The

We appreciate comments and suggestions from Ben Bernanke, Lawrence Christiano, Gauti Eggertson, Martin Eichenbaum, Joe Gagnon, Vito Gaspar, Fabio Ghironi, Marvin Goodfriend, Dale Henderson, Robert King (the editor), Ben McCallum, Edward Nelson, Jeremy Rudd, Lars Svensson, and seminar participants at the European Central Bank, the Federal Reserve Banks of Minneapolis and Richmond, the Federal Reserve Board, Georgetown University, the NBER Summer Institute, the Society for Economic Dynamics and Control, and the University of Michigan. The views expressed in this paper are solely the responsibility of the authors and should not be interpreted as reflecting the views of the Board of Governors of the Federal Reserve System or of any other person associated with the Federal Reserve System.

${ }^{1}$ Notable examples include Hamburger (1967), Parks (1974), Mishkin (1976), Mankiw (1985), Gali (1993), and Baxter (1996).

2 For example, Rotemberg and Woodford (1997) consider an economy with a continuum of producers that manufacture differentiated non-durable goods; see also Goodfriend and King (1997), King and Wolman (1999), Erceg et al. (2000), and Fuhrer (2000). 
structural parameters are calibrated so that the each sector's output response to a monetary innovation roughly matches the VAR impulse response functions. Using estimated time-series processes for each sector's total factor productivity and for government spending, the model also exhibits an empirically realistic degree of sectoral output volatility and comovement. Following the seminal analysis of Rotemberg and Woodford (1997), we obtain a quadratic approximation to the social welfare function, and show that the deviation of welfare from its Pareto-optimal level depends on the variances of sectoral output gaps and on the cross-sectional dispersion of wages and prices in each sector. Finally, we characterize the properties of the optimal policy under commitment, and compare its performance with simple rules that respond only to aggregate variables.

In this setting, sectoral heterogeneity presents a clear challenge to monetary policy: with only a single instrument, the central bank cannot simultaneously stabilize the output gaps of both sectors. We show that the optimal policy places a disproportionately large weight on the durables sector (that is, relative to its small share in the economy); nevertheless, the cross-sectional dispersion of wages and prices and the volatility of the output gap in the durables sector are several times higher than in the non-durables sector and account for a relatively large fraction of welfare deviations from the Pareto-optimal level.

In evaluating the performance of simple monetary policy rules, we find that strict price inflation targeting induces relatively high volatility in sectoral output gaps-especially in the durables sectorand hence performs very poorly in terms of social welfare. Given that the welfare function involves sector-specific variables, one might expect to obtain relatively poor welfare outcomes from any rule that responds solely to aggregate variables. In fact, however, we find that the optimal policy is closely approximated by a simple rule that targets an appropriately-weighted average of aggregate price and wage inflation; this rule may be viewed as a generalized form of inflation targeting in which the underlying basket includes an index of labor costs (Erceg et al, 2000; Mankiw and Reis, 2003). 
The remainder of this paper is organized as follows: Section 2 presents empirical evidence on sectoral responses to monetary policy shocks. Section 3 outlines the dynamic general equilibrium model, and Section 4 describes the solution method and parameter calibration. Section 5 discusses the second order approximation to the welfare function. Section 6 examines characteristics of the optimal policy, and evaluates the performance of alternative policy rules. Section 8 concludes.

\section{Empirical Evidence}

A large literature has utilized identified VARs to measure the response of aggregate output and prices to a monetary policy shock (cf. Sims 1980; Christiano, Eichenbaum, and Evans 1999). Here we follow this approach to investigate the extent to which a policy innovation has differential effects on the consumer durables sector compared with other sectors of the economy. ${ }^{3} \quad$ In the two-sector model developed below, we will abstract from endogenous capital accumulation and focus solely on the behavior of durable expenditures that contribute directly to household utility; thus, we now proceed to disaggregate real GDP into two types of expenditures: a chain-weighted index of consumer durables and residential investment, and a chain-weighted composite of all other GDP components (including business investment). $\quad$ Moreover, insofar as our analytic work will consider sector-specific price dynamics, we also construct a chain-weighted price index for each type of expenditure. We formulate a 6 -variable VAR that includes the logarithms of these expenditure variables and price indices, along with the logarithm of the IMF commodity price index and the level of the federal funds rate. We use ordinary least squares to estimate this VAR-with a lag order of 4-over the sample period 1980:1 to 2000:4.

To identify the impact of a monetary policy innovation, we obtain the Cholesky decomposition of the VAR (using the variables in the same order as in the previous paragraph) and then compute

\footnotetext{
3 Recent work by Christiano, Eichenbaum, and Evans (2001) and Angeloni et al. (2003) has investigated the response of aggregate consumption and investment to a monetary policy shock in a just-identified VAR framework, but does not specifically examine the response of consumer durables and residential investment.

4 These chain-weighted sectoral measures are constructed using the Tornqvist approximation discussed by Whe$\operatorname{lan}(2000)$.
} 
the impulse response functions (IRFs) to a one-standard-deviation innovation to the federal funds rate. The approximate 95 percent confidence bands for each IRF are constructed using 500 Monte Carlo replications.

As shown in Figure 1, the monetary policy shock causes a decline in our broad measure of consumer durables spending that is over three times as large as for the other GDP components. In particular, this innovation generates an initial 60 basis point funds rate increase that is gradually reversed over the next several quarters. Spending on consumer durables exhibits a peak decline of about 0.7 percent in the third quarter following the shock, while the maximum response of spending on other GDP components is only 0.2 percent. Given that the latter category accounts for about 85 percent of nominal GDP on average over the sample period, it is not surprising that the magnitude of its response is similar to that obtained for total GDP in a typical 4-variable VAR that also includes the GDP deflator, commodity prices and the short-term interest rate. ${ }^{5}$ It is also evident that the price decline in each sector is much more gradual than the output decline, suggesting the importance of short-run nominal inertia; interestingly, there is little evidence of a "price puzzle" in the responses of these sectoral price indexes.

\section{The Model}

Our model consists of two sectors that produce distinct types of output, namely, durable and non-durable consumption goods. Labor and product markets in each sector exhibit monopolistic competition, and sectoral wages and prices are determined by staggered four-quarter nominal contracts. Each sector has a fixed capital stock. Each household has two types of workers that are permanently tied to their respective productive sectors. Household preferences are separable both in the consumption of the two goods and in work effort supplied to the two sectors. As shown

\footnotetext{
5 For the purposes of sensitivity analysis, we have also estimated an 8-variable VAR that breaks the GDP expenditure components and corresponding price indexes into three components. These include our broad measure of consumer durables, total business investment, and the remainder of GDP. The point estimates of the IRFs of our broad measure of consumer durables and of the residual expenditure components of GDP using this latter breakdown turn out to be very similar to the responses shown in Figure 1; however, the confidence bands are noticeably wider.
} 
below, these assumptions enable us to obtain a relatively simple expression for social welfare that can decomposed into distinct components corresponding to each of the two sectors.

\subsection{Firms and Price Setting}

Henceforth we use the subscript $m$ to refer to the sector that produces durable goods ("manufacturing"), while the subscript $s$ refers to the sector that produces non-durables ("services"). Within each sector, a continuum of monopolistically competitive firms (indexed on the unit interval) fabricate differentiated products $Y_{j t}(f)$ for $j \in\{m, s\}$ and $f \in[0,1]$. Because households have identical Dixit-Stiglitz preferences, it is convenient to assume that a representative aggregator combines the differentiated products of each sector into a single sectoral output index $Y_{j t}$ :

$$
Y_{j t}=\left[\int_{0}^{1} Y_{j t}(f)^{\frac{1}{1+\theta_{p j}}} d f\right]^{1+\theta_{p j}}
$$

where $\theta_{p j}>0$. The aggregator chooses the bundle of goods that minimizes the cost of fabricating a given quantity of the sectoral output index $Y_{j t}$, taking the price $P_{j t}(f)$ of each good $Y_{j t}(f)$ as given. The aggregator sells units of each sectoral output index at its unit cost $P_{j t}$ :

$$
P_{j t}=\left[\int_{0}^{1} P_{j t}(f)^{\frac{-1}{\theta_{p j}}} d f\right]^{-\theta_{p j}}
$$

It is natural to interpret $P_{j t}$ as the sectoral price index. The aggregate price index $P_{t}$ (also referred to as the GDP price deflator) is simply defined as:

$$
P_{t}=P_{m t}^{\psi_{m}} P_{s t}^{1-\psi_{m}}
$$

where $\psi_{m}$ is the steady state output share of the manufacturing sector.

The aggregator's demand for each good $Y_{j t}(f)$-or equivalently total household demand for this good - is given by

$$
Y_{j t}(f)=\left[\frac{P_{j t}(f)}{P_{j t}}\right]^{\frac{-\left(1+\theta_{p j}\right)}{\theta_{p j}}} Y_{j t}
$$

for $j \in\{m, s\}$ and $f \in[0,1]$. 
Each differentiated good is produced by a single firm that hires capital services $K_{j t}(f)$ and a labor index $L_{j t}(f)$ defined below. All firms within each sector face the same Cobb-Douglas production function, with an identical level of total factor productivity $A_{j t}$ :

$$
Y_{j t}(f)=A_{j t} K_{j t}(f)^{\alpha_{j}} L_{j t}(f)^{1-\alpha_{j}}
$$

Capital and labor are perfectly mobile across the firms within each sector, but cannot be moved between sectors. Furthermore, each sector's total capital stock is fixed at $\bar{K}_{j}$. Each firm chooses $K_{j t}(f)$ and $L_{j t}(f)$, taking as given the sectoral rental price of capital $P_{j t}^{k}$ and the sectoral wage index $W_{j t}$ defined below. The standard static first-order conditions for cost minimization imply that all firms within each sector have identical marginal costs per unit of output $\left(M C_{j t}\right)$.

We assume that the prices of intermediate goods are determined by staggered nominal contracts of fixed duration (as in Taylor, 1980). Each price contract lasts four quarters, and one-fourth of the firms in each sector reset their prices in a given period. Whenever the firm is not allowed to reset its contract, the firm's price is automatically increased at the unconditional mean rate of gross inflation, П. Thus, if firm $f$ in sector $j$ has not adjusted its contract price since period $t$, then its price $i$ periods later is given by $P_{j, t+i}(f)=P_{j t}(f) \Pi^{i}$.

When a firm is allowed to reset its price in period $t$, the firm maximizes the following profit functional with respect to its contract price, $P_{j t}(f)$ :

$$
\mathcal{E}_{t} \sum_{i=0}^{3} \psi_{t, t+i}\left(\left(1+\tau_{p j}\right) \Pi^{i} P_{j t}(f) Y_{j, t+i}(f)-M C_{j, t+i} Y_{j, t+i}(f)\right)
$$

The operator $\mathcal{E}_{t}$ represents the conditional expectation based on information through period $t$. The firm discounts profits received at date $t+i$ by the state-contingent discount factor $\psi_{t, t+i}$ (for notational simplicity, we have suppressed state indices from this expression). The firm's output is subsidized at a fixed rate $\tau_{p j}$ that is set to eliminate the monopolistic distortion in each sector; that is, $\tau_{p j}=\theta_{p j}$ for $j \in\{m, s\}$. Thus, in the steady state of the model, prices are equated to marginal cost in each sector, or equivalently, the sectoral marginal product of labor is equal to the sectoral real wage, as in a perfectly competitive economy. 


\subsection{Households and Wage Setting}

We assume that there is a continuum of households indexed on the unit interval, and that each household supplies differentiated labor services. Within every household, a fixed number of members $\nu_{m}$ work exclusively in the manufacturing sector, while the remaining $\nu_{s}$ members work exclusively in the service sector. Each member of a given household $h \in[0,1]$ who works in a given sector $j \in\{m, s\}$ has the same wage rate $W_{j t}(h)$ and supplies the same number of hours $N_{j t}(h)$. As in the firm's problem described above, it is convenient to assume that a representative labor aggregator (or "employment agency") combines individual labor hours into a sectoral labor index $L_{j t}$ using the same proportions that firms would choose:

$$
L_{j t}=\nu_{j}\left[\int_{0}^{1} N_{j t}(h)^{\frac{1}{1+\theta_{w j}}} d h\right]^{1+\theta_{w j}}
$$

where $\theta_{w j}>0$. The aggregator minimizes the cost of producing a given amount of the aggregate labor index, taking the wage rate $W_{j t}(h)$ for each household member as given, and then sells units of the labor index to the production sector at unit cost $W_{j t}$ :

$$
W_{j t}=\left[\int_{0}^{1} W_{j t}(h)^{\overline{\theta_{w j}}} d h\right]^{-\theta_{w j}}
$$

It is natural to interpret $W_{j t}$ as the sectoral wage index. The aggregator's demand for the labor hours of household $h$ - or equivalently, the total demand for this household's labor by all goodsproducing firms - is given by

$$
\nu_{j} N_{j t}(h)=\left[\frac{W_{j t}(h)}{W_{j t}}\right]^{-\frac{1+\theta_{w i}}{\theta_{w j}}} L_{j t}
$$

In each period, the household purchases $Y_{m t}(h)$ units of durable goods at price $P_{m t}$, and $C_{t}(h)$ units of non-durable goods (or services) at price $P_{s t}$. To generate a source of demand for money, we assume that non-durables must be purchased using cash balances, while durable goods can be purchased using credit. The household's stock of durable goods $D_{t}(h)$ evolves as follows:

$$
D_{t+1}(h)=(1-\delta) D_{t}(h)+Y_{m t}(h)
$$


where the depreciation rate $\delta$ satisfies the condition $0<\delta \leq 1$.

The household's expected lifetime utility is given by

$$
\mathcal{E}_{t} \sum_{i=0}^{\infty} \beta^{i} \mathbb{W}_{t+i}(h)
$$

The operator $\mathcal{E}_{t}$ here represents the conditional expectation over all states of nature, and the discount factor $\beta$ satisfies $0<\beta<1$. The period household utility function $\mathbb{W}_{t}(h)$ is additively separable with respect to the household's durables stock $D_{t}(h)$, its consumption of non-durables $C_{t}(h)$, the leisure of each household member, and the household's nominal money balances $M_{t}(h)$ deflated by the price index of non-durables $P_{s t}$ :

$$
\mathbb{W}_{t}(h)=\mathbb{U}\left(\widetilde{D}_{t}(h)\right)+\mathbb{S}\left(C_{t}(h)\right)+\mathbb{V}\left(N_{m t}(h)\right)+\mathbb{Z}\left(N_{s t}(h)\right)+\mathbb{M}\left(\frac{M_{t}(h)}{P_{s t}}\right)
$$

In particular, the household receives period utility $\mathbb{U}\left(\widetilde{D}_{t}(h)\right)$ from its current durables stock net of adjustment costs, $\widetilde{D}_{t}(h)$ :

$$
\mathbb{U}\left(\widetilde{D}_{t}(h)\right)=\frac{\sigma_{m_{0}}\left[\widetilde{D}_{t}(h)\right]^{1-\sigma_{m}}}{1-\sigma_{m}}
$$

where

$$
\widetilde{D}_{t}(h)=D_{t}(h)-0.5 \phi \frac{\left(Y_{m t}(h)-\delta D_{t}(h)\right)^{2}}{D_{t}(h)}
$$

and the parameters $\sigma_{m_{0}}>0, \sigma_{m}>0$ and $\phi \geq 0$. The remaining components of period utility are given as follows:

$$
\begin{gathered}
\mathbb{S}\left(C_{t}(h)\right)=\frac{\left[C_{t}(h)\right]^{1-\sigma_{s}}}{1-\sigma_{s}} \\
\mathbb{V}\left(N_{m t}(h)\right)=v_{m} \frac{\left[1-N_{m t}(h)\right]^{1-\chi_{m}}}{1-\chi_{m}} \\
\mathbb{Z}\left(N_{s t}(h)\right)=v_{s} \frac{\left[1-N_{s t}(h)\right]^{1-\chi_{s}}}{1-\chi_{s}} \\
\mathbb{M}\left(\frac{M_{t}(h)}{P_{s t}}\right)=\frac{\mu_{0}}{1-\mu}\left(\frac{M_{t}(h)}{P_{s t}}\right)^{1-\mu}
\end{gathered}
$$


where the parameters $\sigma_{s}, \chi_{m}, \chi_{s}, \mu$, and $\mu_{0}$ are all strictly positive.

Household $h$ 's budget constraint in period $t$ states that consumption expenditures plus asset accumulation must equal disposable income:

$$
\begin{gathered}
P_{m t} Y_{m t}(h)+P_{s t} C_{t}(h) \\
+M_{t+1}(h)-M_{t}(h)+\int \gamma_{t, t+1} B_{t+1}(h)-B_{t}(h) \\
=\nu_{m}\left(1+\tau_{w m}\right) W_{m t}(h) N_{m t}(h)+\nu_{s}\left(1+\tau_{w s}\right) W_{s t}(h) N_{s t}(h) \\
+\Gamma_{m t}(h)+\Gamma_{s t}(h)-T_{t}(h)
\end{gathered}
$$

Financial asset accumulation consists of increases in money holdings and the net acquisition of state-contingent claims. The state price $\gamma_{t, t+1}$ represents the price of an asset that will pay one unit of currency in a particular state of nature in the subsequent period, while $B_{t+1}(h)$ represents the quantity of such claims purchased by the household at time $t$. Total expenditure on new state-contingent claims is given by integrating over all states at time $t+1$, while $B_{t}(h)$ indicates the value of the household's existing claims given the realized state of nature. Disposable income consists of the sum of wage income (which is subsidized at a fixed rate $\tau_{w j}$ in each sector) and an aliquot share $\Gamma_{j t}(h)$ of each sector's profits and rental income, minus a lump-sum tax $T_{t}(h)$ that is paid to the government.

Each household $h$ maximizes its expected lifetime utility with respect to its consumption of services, purchases of durables, holdings of money, and its holdings of contingent claims, subject to its budget constraint, equation (19). Moreover, nominal wage rates in each sector are determined by staggered four quarter wage contracts that are similar in form to the price contracts discussed earlier. During the quarter in which the household renegotiates its labor contract, it chooses its wage rate in each sector to maximize its expected lifetime utility, subject to the demand for its labor in each sector, equation (9), and its budget constraint. Whenever the household is not 
allowed to reset the wage contract, the wage rate is automatically increased at the unconditional mean rate of gross inflation, $\Pi$. We assume that employment is subsidized to eliminate the monopolistic distortion in each sector; that is, $\tau_{w j}=\theta_{w j}$ for $j \in\{m, s\}$. Thus, the steady state of the model satisfies the efficiency condition that the marginal rate of substitution in each sector equals the real wage, as in a perfectly competitive economy.

\subsection{Fiscal and Monetary Policy}

The government's budget is balanced every period, so that total lump-sum taxes plus seignorage revenue are equal to output and labor subsidies plus the cost of government purchases:

$$
\begin{gathered}
M_{t}-M_{t-1}+\int_{0}^{1} T_{t}(h) d h=\int_{0}^{1} \tau_{m} P_{m t}(f) Y_{m t}(f) d f+\int_{0}^{1} \tau_{s} P_{s t}(f) Y_{s t}(f) d f \\
\quad+\int_{0}^{1} \tau_{w m} W_{m t}(h) \nu_{m} N_{m t}(h) d h+\int_{0}^{1} \tau_{w s} W_{s t}(h) \nu_{S} N_{s t}(h) d h+P_{s t} G_{t}
\end{gathered}
$$

where $G_{t}$ indicates real government purchases from the service sector. Finally, the total output of the service sector is subject to the following resource constraint:

$$
Y_{s t}=C_{t}+G_{t}
$$

We assume that the short-term nominal interest rate is used as the instrument of monetary policy, and that the policymaker is able to commit to a time-invariant rule. We consider alternative specifications of the monetary policy rule in our analysis, including both rules that can be regarded as reasonable characterizations of recent historical experience, and rules derived from maximizing a social welfare function.

\section{Solution and Calibration}

To analyze the behavior of the model, we log-linearize the model's equations around the nonstochastic steady state. Nominal variables, such as the contract price and wage, are rendered stationary by suitable transformations. We then compute the reduced-form solution of the model 
for a given set of parameters using the numerical algorithm of Anderson and Moore (1985), which provides an efficient implementation of the solution method proposed by Blanchard and Kahn (1980).

\subsection{Parameters of Private Sector Behavioral Equations}

The model is calibrated at a quarterly frequency. Thus, we assume that the discount factor $\beta=$ .993, consistent with a steady-state annualized real interest rate $\bar{r}$ of about 3 percent. We assume that the preference parameters $\sigma_{m}=\sigma_{s}=2$, implying that preferences over both durables and non-durables exhibit a somewhat lower intertemporal substitution elasticity than the logarithmic case; these settings for the preference parameters are well within the range typically estimated in the empirical literature. The leisure preference parameters $\chi_{m}=\chi_{s}=3 .{ }^{6} \quad$ The capital share parameters $\alpha_{m}=\alpha_{s}=0.3$. The quarterly depreciation rate of the durables stock $\delta=0.025$, implying an annual depreciation rate of 10 percent. This choice reflects that the durables sector in our model includes both consumer durables and residential investment, which have annual depreciation rates of about 20 percent and 3 percent, respectively, and that the expenditure share of consumer durables in the composite is about two-thirds. The sectoral price and wage markup parameters $\theta_{P s}=\theta_{W s}=\theta_{P m}=\theta_{W m}=0.3$. As noted above, price and wage contracts in each sector are specified to last four quarters. The share of the durables sector in both output and employment $\psi_{m}$ is set equal to 0.125 , implying that the share of services $\psi_{s}=0.875$ (this determines the employment size parameters $\nu_{s}$ and $\nu_{m}$ in the subutility functions for leisure). The share of government spending in non-durables production $\left(S_{G}^{s}\right)$ is set to 0.18 , implying that the government share of total output is about 16 percent. Finally, as described below, we set the cost of adjusting the stock of durables parameter $\phi=600$ in order to match the magnitude of the response of durable goods output to a monetary innovation.

\footnotetext{
${ }^{6}$ We scale the level of capital to hours worked in each sector so that the ratio of hours worked to leisure (denoted $\ell_{j}$ below) equals $1 / 2$ in the steady state in each sector. We choose the scaling parameter in the subutility function for durables $\sigma_{m_{0}}$ so that the relative price of durables in terms of non-durables is equal to unity in the steady state.
} 


\subsection{Monetary Policy Rule}

In our baseline specification, we assume that the central bank adjusts the short-term nominal interest rate in response to the four-quarter average inflation rate and to the current and lagged output gaps:

$$
i_{t}=\gamma_{i} i_{t-1}+\gamma_{\pi} \pi_{t}^{(4)}+\gamma_{y, 1} g_{t}+\gamma_{y, 2} g_{t-1}+e_{t}
$$

where the four-quarter average inflation rate $\pi_{t}^{(4)}=\frac{1}{4} \sum_{j=0}^{3} \pi_{t-j}, g_{t}$ is the aggregate output gap, and $e_{t}$ is a monetary policy innovation; note that constant terms involving the inflation target and steady-state real interest rate are suppressed for simplicity. Orphanides and Wieland (1998) found that this specification provides a good in-sample fit to U.S. data over the 1980:1-1996:4 sample period, and obtained the following parameter estimates: $\gamma_{i}=0.795, \gamma_{\pi}=0.625, \gamma_{y, 1}=1.17$, $\gamma_{y, 2}=-0.97$, and $\operatorname{std}\left(e_{t}\right)=0.0035$.

\subsection{Evolution of Real Shocks}

In addition to the monetary policy innovation, our model includes three exogenous stochastic variables: total factor productivity in the production of durables $\left(A_{m t}\right)$, total factor productivity in non-durables $\left(A_{s t}\right)$, and government spending on non-durables $\left(G_{t}\right)$.

These three exogenous variables are assumed to follow a trivariate first-order VAR:

$$
\left[\begin{array}{c}
A_{m t} \\
A_{s t} \\
G_{t}
\end{array}\right]=\left[\begin{array}{ccc}
\rho_{m} & 0 & 0 \\
0 & \rho_{s} & 0 \\
0 & 0 & \rho_{G}
\end{array}\right]\left[\begin{array}{c}
A_{m t-1} \\
A_{s t-1} \\
G_{t-1}
\end{array}\right]+\left[\begin{array}{c}
e_{m t} \\
e_{s t} \\
e_{G t}
\end{array}\right]
$$

where the innovations are assumed to be i.i.d. with contemporaneous covariance matrix $\Sigma$. While we allow for innovations to sectoral productivity to be correlated contemporaneously, government spending innovations and monetary innovations are assumed to be uncorrelated both with each other, and with the innovations to productivity. Accordingly, we estimate a univariate first-order 
autoregression for government spending over the 1980:1-2000:4 sample period (the shorter sample period used in our VAR estimation in Section 2), and find that $\rho_{G}=0.92$, and $\operatorname{std}\left(e_{G t}\right)=.031 .^{7}$ Next, we estimate the parameters of the bivariate technology shock process using the method of moments. In particular, we choose the five parameters determining the persistence, variance, and covariance of the technology shocks so that our model's implications for the standard deviation of sectoral outputs, their first order autocorrelation, and their contemporaneous correlation are exactly consistent with the corresponding sample moments. Our moment-matching procedure takes as given the other structural parameters of our model, including the standard deviation of the monetary innovation, and the estimated process for government spending. In estimating the sample moments, we employ the same data utilized in estimating the VAR associated with Figure 1. ${ }^{8}$ Our procedure yields estimates of $\rho_{s}=.87, \rho_{m}=.90, \operatorname{std}\left(e_{s t}\right)=.0096, \operatorname{std}\left(e_{m t}\right)=.0360$, and $\operatorname{corr}\left(e_{m t}, e_{s t}\right)=.29$.

\section{The Welfare Function}

To provide a normative assessment of alternative monetary policy choices, we measure social welfare as the unconditional expectation of average household lifetime utility:

$$
S W=\mathcal{E} \int_{0}^{1}\left[\sum_{i=0}^{\infty} \beta^{t} \mathbb{W}_{t}(h)\right] d h
$$

We follow the seminal analysis of Rotemberg and Woodford (1997) in deriving the second-order approximation to the social welfare function and computing its deviation from the welfare of the Pareto-optimal equilibrium under flexible wages and prices. For a heuristic description of the welfare function, it is helpful to recall from equation (12) that the period household utility function $\mathbb{W}_{t}(h)$ is comprised of the following additively-separable components: two terms involving the

\footnotetext{
7 We measure government spending as the nonwage component of government consumption spending.

8 Thus, "durables" is measured as a chain-weighted composite of consumer durables and residential investment, "nondurables" as other expenditure components of GDP, and the sample period is 1980:1-2000:4. After removing a $\log$-linear trend, we found the quarterly standard deviation of nondurables to be 1.61 percent, of durables 8.69 percent, the autocorrelation of nondurables 0.88 , of durables 0.92 , and the contemporaneous correlation 0.40 .
} 
non-durables sector $\left(\mathbb{S}\left(C_{t}(h)\right)\right.$ and $\left.\mathbb{Z}\left(N_{s t}(h)\right)\right)$; two terms involving the durables sector $\left(\mathbb{U}\left(\widetilde{D}_{t}(h)\right)\right.$ and $\left.\mathbb{V}\left(N_{m t}(h)\right)\right)$; and one term that depends on real money balances $\left(\mathbb{M}\left(\frac{M_{+}(h)}{P_{s t}}\right)\right)$. The terms associated with the non-durables sector can be expressed in essentially the same form as obtained by Erceg, Henderson, and Levin (2000); that is, this component of welfare depends on the variance of the sectoral output gap ${ }^{9}$ and on the magnitude of cross-sectional dispersion in prices and wages in this sector. As shown in the technical appendix to this paper, approximating the components of welfare associated with the durables sector yields parallel expressions involving the variance of the sectoral output gap and the cross-sectional dispersion of wages and prices in this sector, as well as some additional terms (arising from the durability of output and from quadratic adjustment costs) that make relatively minor contributions to the welfare results reported below. ${ }^{10}$ Finally, we assume that the preference parameter $\mu_{0}$ is arbitrarily small, enabling us to abstract from the welfare implications of fluctuations in real money balances.

While the key terms in the welfare function are roughly analogous to those obtained from a onesector model, it should be noted that our assumption of fixed-duration ("Taylor-style") contracts has important implications for the welfare costs of inflation volatility. ${ }^{11}$ Under the commonly-used specification of random-duration ("Calvo-style") contracts, some contracts remain unchanged over long stretches of time, even if the average contract duration is relatively short; thus, fluctuations in aggregate inflation tend to have highly persistent effects on cross-sectional dispersion, so that the welfare cost of wage and price inflation volatility are at least an order of magnitude greater than the welfare cost of output gap volatility (cf. Rotemberg and Woodford 1997; Erceg et al. 2000). In contrast, fixed-duration contracts induce much less persistence of cross-sectional dispersion, and hence imply that the welfare cost of relative price and wage dispersion is roughly comparable

\footnotetext{
9 The output gap in each sector is defined as the difference between output in that sector and the level of output that would prevail in the case of fully flexible prices and wages.

10 The technical appendix is an attachment to the revised version of our working paper (International Finance Discussion paper no. 748); both are available on the Federal Reserve Board's website.

11 Under fixed-duration contracts, the welfare costs of cross-sectional dispersion cann ot be summarized solely in terms of the variances of wage and price inflation, but must be given explicitly in terms of the variances of relative wages and prices.
} 
in magnitude to the costs of output gap volatility. For example, using our baseline calibration with Taylor-style contracts, the weights on the relative price and wage dispersion terms in the non-durables component of the welfare function are 0.86 and 4.54, respectively, when expressed as a ratio to the weight on the output gap term. By contrast, using the same calibration except with Calvo-style contracts (with a mean duration of four quarters), the relative weights are 10.4 and 54.5, respectively.

\section{Results}

We begin by illustrating the implications of durable goods and nominal rigidities in sectoral output prices for the stabilization problem faced by the monetary authority. Specifically, we compare the effects of two different real shocks under the full-commitment optimal policy in our benchmark model with the case in which all prices and wages are fully flexible. Our analysis provides intuition for why the output of the durables sector is relatively volatile even under the optimal policy, and shows how the inclusion of durables affects the interest rate response to the real shocks. Moreover, given that sectoral output gap volatility is a key determinant of welfare (even if not exclusive), this graphical analysis is instrumental in understanding the subsequent section that examines welfare under the optimal rule and some simple alternatives.

\subsection{Tradeoffs under the Optimal Policy}

The dotted line in Figure 2 shows the effects of a positive one standard deviation innovation to (total factor) productivity in the non-durables sector in the special case in which both sectoral prices and wages are fully flexible (which we refer to below as the "flexible price" equilibrium). The shock induces an immediate rise in non-durables output (upper right panel), and corresponding fall in the real interest rate measured in units of the nondurable good (lower left panel). Given that household preferences are separable both in the consumption of the two goods and in work effort supplied to each sector, durable-goods output (upper left panel) is completely unaffected by the shock. While the higher consumption of nondurables raises the demand for durable goods, 
this effect is exactly offset by a rise in the user cost associated with a jump in the relative price of durables (lower right panel).

To clarify how adjustment in the relative price of durables insulates the durable goods sector from the shock to non-durables, it is helpful to examine the log-linearized first order condition determining the stock demand for new durable goods $\left(d_{t+1}\right)$ :

$$
\begin{aligned}
& d_{t+1}=c_{t}-\frac{1}{\sigma_{m}} z_{t}+\phi \mathcal{E}_{t}\left[\Delta d_{t+2}-(1 / \beta) \Delta d_{t+1}\right] \\
& z_{t}=q_{t}+\left(\frac{1-\delta}{r+\delta}\right) \mathcal{E}_{t}\left[r_{s t}-\Delta q_{t+1}\right]
\end{aligned}
$$

While the rise in nondurable consumption $\left(c_{t}\right)$ would augment the demand for durables if the user cost $\left(z_{t}\right)$ remained constant, the user cost rises due to a increase in the asset price $\left(q_{t}\right)$, and through the expectation of a future capital loss on holding the durable (so that $\Delta q_{t+1}<0$ ). The sharp and immediate relative price adjustment is a hallmark feature of the flexible price equilibrium.

By contrast, it is clear that monetary policy faces a tradeoff in our benchmark model: even under the full commitment optimal rule, monetary policy is unable to to keep output at potential in each sector. As seen in Figure 2, the shock to non-durables productivity has a peak effect on the output gap in durables of about 1 percentage point, more than twice the magnitude of the peak effect on the output gap in non-durables (recalling that the latter is the difference between the level of output in non-durables, the solid line, and the level in the flexible price equilibrium, the dotted line). From a qualitative perspective, a similar tradeoff would emerge even if each sector produced a non-durable good. However, two factors that are particular to durables play an important role in accounting for the pronounced magnitude of the output gap response in that sector. First, the demand for durables is for a stock, so that any changes in the stock demand translate into much larger fluctuations in the flow demand for newly-produced goods. Second, the presence of sectoral price rigidities mitigates the role that changes in the relative price of durables play in insulating the durables sector from shocks. Because the relative price of durables adjusts 
only gradually, the change in the user cost due to contemporaneous adjustment of the relative price tends to be offset by the movement in the capital gain component (i.e., $q_{t}>0$, and $\Delta q_{t+1}>$ 0 for the shock considered here). This makes the behavior of durables particularly sensitive to the real interest rate, so that even a modest departure of the real interest rate from the path required to keep durables output at potential may induce a sizeable output gap.

Thus, the productivity shock to non-durables provides a clear illustration of the challenge facing monetary policy in an environment with durable goods and price (and wage) stickiness at the sectoral level. In particular, keeping output at potential in the nondurable sector would require a policy that adjusted the real interest rate (on nondurables) in the manner shown in the case of the flexible price equilibrium, i.e., a sharp and persistent fall in the real interest rate. The latter is also the path of the real interest rate that would obtain in a one-sector model with only non-durable goods under a policy of strict output gap targeting. By contrast, keeping output near potential in durables would require a sharp rise in the real interest rate; otherwise, the expectation of a positive capital gain on durables and the positive wealth effect from the productivity shock would boost output in that sector well above potential. The optimal policy may be regarded as somewhat of a compromise between the two extremes. Real inter est rates rise initially, precluding output in the non-durable sector from rising as much as it would in the flexible price equilibrium, though not enough to forestall a substantial positive output gap in the durables sector.

A similar policy stabilization tradeoff appears in the case of the government spending shock that is shown in Figure 3. Given that the spending rise temporarily depresses consumption of the nondurable good, keeping output at potential in the nondurable sector would require a rise in the real interest rate (as in the case of the flexible price equilibrium shown in the figure). But a sharp reduction in the real interest rate would be required to keep durables output near potential; otherwise, the expectation of a negative capital gain in durables (since the relative price adjusts downward slowly) and negative wealth effect would markedly reduce the demand for durables. Again, the optimal policy represents a compromise, with the real interest rate rising by much less 
than would occur under the flexible price equilibrium.

Thus, durables present the monetary policymaker with a fairly complicated stabilization problem. The inclusion of durables markedly changes the behavior of the real inter est rate relative to the flexible price equilibrium, or equivalently, to the path that would obtain in a one sector model with only non-durable goods (assuming strict output gap targeting). However, even though a significant weight is placed on the durables sector in setting the optimal interest rate policy, there is sizeable variation in the output gap in durables in response to the real shocks considered.

\subsection{Welfare Implications of Alternative Rules}

Although the impulse responses in Figures 2 and 3 focus on sectoral output gaps and do not include the other key ingredients of the social welfare function, they are suggestive that the behavior of the durables sector is relevant both for welfare and the characteristics of the optimal policy to a degree that dwarfs its small share in output and employment. This int uition is confirmed in Table 1. This table reports welfare losses under the optimal rule (row 1) and various alternative policies (rows 2-6) using the quadratic approximation to the social welfare function discussed above. The welfare loss reported in columns 1-3 can be interpreted as the output loss per period under each policy relative to that of the flexible price equilibrium, and is expressed as a percentage of steady state output (multiplied by a constant scale factor of $10^{-2}$ ). ${ }^{12}$ The welfare losses are computed for our benchmark calibration of the model after substituting for the appropriate monetary policy rule, so that welfare depends on the estimated variance-covariance matrix of the three real shocks.

Turning to the case of the optimal rule shown in the first row, it is evident that welfare losses attributable to the durable goods sector exceed welfare losses in non-durables. The higher welfare losses in durables, notwithstanding the much smaller size of that sector, reflect that the standard deviation of the (true) output gap in durables is several times larger than in non-durables, and that the durables sector experiences more volatility in relative wages and prices.

${ }^{12}$ It is important to note that the welfare losses reported in the tables are measured as a flow, and correspond to the expected loss each period under a given policy. Given our parameterization of $\beta=.993$, expected discounted losses are more than 100 times larger than what is reported in the tables. 
We next consider the performance of two alternative rules that respond only to aggregate variables, namely aggregate output gap targeting, and a hybrid rule that targets a weighted average of price and wage inflation. ${ }^{13}$ While aggregate output gap targeting keeps aggregate output exactly at potential, the wage-price rule also succeeds in keeping aggregate output close to potential in our model. Intuitively, the wage-price rule cuts interest rates when both prices and wages are falling, which has the effect of boosting output toward potential; but also guards against allowing output to expand much above potential in the case of favorable supply shocks by reacting to wages (which rise) as well as to prices (which fall). Each of these rules has been shown to perform well relative to the optimal policy in the context of one sector models with nominal wage and price rigidities.

The table indicates that welfare losses under these alternative rules are on the order of 10-20 percent larger than under the optimal rule. The source of the larger welfare losses is that the aggregate rules allow for too much volatility in the durable goods sector, leading to considerably greater losses in the durables component than under the optimal rule: thus, the welfare loss attributable to the durables component under the wage-price rule is almost twice as large as under the optimal rule. Some implications of the fact that these aggregate rules put too little weight on durables are apparent in Figures 2 and 3, which include plots of the responses under the aggregate wage-price targeting rule (the responses under aggregate output gap targeting for each of these shocks are very similar). In the case of the productivity shock to nondurables, interest rates are raised by less than would occur under the optimal rule, so that the productivity shock generates too large a rise in durables output. With the government spending shock, interest rates are raised by more under wage-price targeting than under the optimal rule, inducing a noticeably sharper contraction in the durable goods sector.

\footnotetext{
13 Each of these rules is implemented as a targeting rule, rather than as an instrument rule. In particular, the rule is derived by maximizing a welfare function consistent with the objective in each case subject to the behavioral constraints of the model. In the case of the wage-price targeting rule, we use an objective function with a weight of unity on aggregate price inflation, and of 5.25 on aggregate wage inflation, equal to the relative weight on the price and wage dispersion terms in the social welfare function.
} 
Notwithstanding these shortcomings, the aggregate output gap targeting and the hybrid wageprice targeting rules still perform remarkably well. While it would be desirable to reduce volatility in durables relative to what occurs under these rules, they don't induce enough sectoral volatility to imply pronounced gains in shifting to the optimal rule, at least given the magnitude and characteristics of the estimated shocks. Importantly, these suboptimal rules perform well enough that they generally preclude "free lunches" in moving to the optimal rule, so that any gains from reducing losses in the durables component of welfare are at least partly offset by higher losses in the non-durables component. Thus, the net benefits of a shifting to a rule that responds directly to sectoral variables is fairly low. Of course, with a more volatile distribution of shocks, the difference between the level of volatility in the durable and non-durable sectors would widen under either of these aggregate rules, and there would be greater benefit to following a rule that responded to sectoral variables.

By contrast, the combination of durable goods and sluggish nominal wage adjustment render strict (aggregate) price inflation targeting a very poor policy choice. As seen in row 4 of the table, the welfare loss under inflation targeting is over four times as large as under the optimal rule, reflecting high losses in both the non-durables and durables components. The high losses in non-durables arise through the same channels as in a one sector model with nominal wage rigidity: in the latter case, Erceg et al (2000) have shown that price inflation targeting can induce high volatility in the aggregate output gap and sizeable wage dispersion across households. In our two sector model, the large size of the non-durables sector implies that stabilizing aggregate inflation is nearly tantamount to stabilizing the non-durables inflation rate. But this generates pronounced output gap volatility in non-durables, because changes in the non-durables output gap must play a dominant role in offsetting the direct effects of shocks to unit labor costs. This is illustrated in Figure 2, where it is evident that the output gap in non-durables must expand a great deal to offset the downward pressure on unit labor costs associated with the productivity improvement. The large cut in real interest rates required to stabilize price inflation also has a highly stimulative 
effect on the durable goods sector: with interest rates low and households expecting a capital gain on durables, there is a large increase in the stock demand for durables, and a boom in production. The high output gap volatility in durables and associated wage dispersion account for the large losses in that component of welfare.

Finally, Table 1 also presents welfare losses under the estimated historical monetary policy rule, and under the Taylor Rule. The estimated rule exhibits some deterioration in performance relative to aggregate output gap targeting and the hybrid wage-price rule, in part because it is less successful in minimizing welfare losses in durables. There is a considerably larger deterioration under Taylor's rule, including in the non-durables component of welfare, as the Taylor rule permits relatively persistent deviation of output from potential.

\section{Conclusions}

Our analysis indicates that it may not be necessary for a well-designed monetary policy rule to respond to sector-specific variables, even if social welfare depends explicitly upon them. In particular, while it seems clear that aggressive stabilization of final goods prices is undesirable, our results suggest that a somewhat broader concept of inflation-targeting in which the underlying basket is comprised of an index of both final goods prices and aggregate labor costs may perform well. With the appropriately chosen weights on aggregate price and wage inflation, such a policy comes close to stabilizing aggregate output at potential. Furthermore, given the estimated distribution of shocks, the level of sectoral output dispersion is reasonably close to that implied by the optimal full-commitment rule. Such a rule is clearly easier to implement and convey to market participants than the full-commitment rule. Moreover, while it achieves a similar outcome as a rule that directly targets the (true) aggregate output gap, it does not require direct knowledge of the level of potential output.

Our finding that simple aggregate rules can perform well may seem surprising given that certain features of our model framework-including the inability of resources to move across sectors-would 
appear to favor a rule involving sector-specific variables. In future research, it will be desirable to explore this further by allowing for intersectoral factor mobility subject to adjustment costs, and also by incorporating other empirically-realistic dynamic complications (such as endogenous capital accumulation by firms). Finally, it will be interesting to consider the implications of alternative shocks, including shocks that may arise in an open-economy setting. In the presence of shocks that generated a much higher degree of cross-sectional output dispersion, there would be larger potential gains in responding to sector-specific variables than indicated by our analysis. 


\section{References}

Anderson, G.S., Moore, G., 1985, A linear algebraic procedure for solving linear perfect foresight models, Economic Letters 17, 247-252.

Angeloni, Ignazio, Kashyap, Anil, Mojon, Benoit, and Daniele Terlizzese, 2003, The Output Consumption Puzzle: A Difference in the Monetary Transmission Mechanism in the Euro Area and United States, Journal of Money, Credit, and Banking 35, 1265-1306.

Baxter, Marianne, 1996, Are Consumer Durables Important for Business Cycles? Review of Economics and Statistics 78, 147-155.

Blanchard, Olivier and Charles Kahn, 1980, The Solution of Linear Difference Models under Rational Expectations, Econometrica 48, 1305-1311.

Calvo, Guillermo, 1983, Staggered Prices in a Utility Maximizing Framework, Journal of Monetary Economics 12, 383-98.

Christiano, Lawrence and Martin Eichenbaum, 1992, Current Real-Business Cycle Theories and Aggregate Labor Market Fluctuations, American Economic Review 82, 430-450.

Christiano, Lawrence, Eichenbaum, Martin, and Charles Evans, 1999, Monetary Policy Shocks: What Have We Learned, and to What End? In: Taylor, John and Michael Woodford (Eds.), Handbook of Macroeconomics, Vol 1A, 65-148.

Christiano, Lawrence, Eichenbaum, Martin, and Charles Evans, 2001, Nominal Rigidities and the Dynamic Effects of Shocks to Monetary Policy, National Bureau of Economic Research Working Paper no. 8403.

Clarida, Richard, Jordi Gali, and Mark Gertler, 2000, Monetary Policy Rules and Macroeconomic Stability: Evidence and Some Theory, Quarterly Journal of Economics 115, 147-180. 
Erceg, Christopher, Dale Henderson, and Andrew Levin, 2000, Optimal Monetary Policy with Staggered Wage and Price Contracts, Journal of Monetary Economics 46, 281-313.

Erceg, Christopher, and Andrew Levin, 2005, Optimal Monetary Policy with Durable Consumption Goods, International Finance Discussion Paper no. 748.

Fuhrer, Jeffrey, 2000, Habit Formation in Consumption and Its Implications for Monetary-Policy Models, American Economic Review 90, 367-90.

Gali, Jordi, 1993, Variability of Durable and non-durable Consumption: Evidence for Six OECD Countries, Review of Economics and Statistics 75, 418-428.

Goodfriend, Marvin, 1997, Monetary Policy Comes of Age: A 20th Century Odyssey, Federal Reserve Bank of Richmond Economic Quarterly 83, 1-24.

Goodfriend, Marvin and Robert King, 1997, The New Neoclassical Synthesis and the Role of Monetary Policy, in: Bernanke, B.S., Rotemberg, J.J. (eds.), NBER Macroeconomics Annual 1997 (MIT Press: Cambridge), 231-283.

Hamburger, Michael J. 1967, Interest Rates and the Demand for Consumer Durable Goods, American Economic Review 57:5, 1131-1153.

Henderson, Dale and Warwick McKibbin, 1993, A Comparison of Some Basic Monetary Policy Regimes for Open Economies: Implications of Different Degrees of Instrument Adjustment and Wage Persistence, Carnegie-Rochester Series on Public Policy 39, 221-318.

Hornstein, Andreas and Jack Prashnik, 1997, Intermediate Inputs and Sectoral Comovement in the Business Cycle, Journal of Monetary Economics 40, 573-95.

King, Robert., Wolman, Alexander, 1999, What Should the Monetary Authority Do When Prices are Sticky? In: Taylor, J. (ed.), Monetary Policy Rules, (University of Chicago Press: Chicago), 349-398. 
Mankiw, Gregory, and Ricardo Reis, 2003, What Measure of Inflation Should a Central Bank Target? Journal of the European Economic Association 1, 1058-86.

Mishkin, Frederic, 1976, Illiquidity, Consumer Durable Expenditure, and Monetary Policy, American Economic Review 66, 642-654.

Ogaki, Masao and Carmen M. Reinhart, 1998, Measuring Intertemporal Substitution: The Role of Durable Goods, Journal of Political Economy 106, 1078-1098.

Orphanides, Athanasios, and Volker Wieland, 1998, Price Stability and Monetary Policy Effectiveness when Nominal Interest Rates are Bounded at Zero, Finance and Economics Discussion Paper no. 98-35, Washington, D.C.: Board of Governors of the Federal Reserve System.

Parks, Richard, 1974, The Demand and Supply of Durable Goods and Durability, American Economic Review 64, pp. 37-55.

Rotemberg, Julio and Michael Woodford, An Optimization-Based Econometric Framework for the Evaluation of Monetary Policy. in: Bernanke, Ben and Julio Rotemberg (eds.), NBER Macroeconomics Annual 199\%. (MIT Press: Cambridge), 297-346.

Sims, Christopher, 1980, Macroeconomics and Reality, Econometrica 48, 1-48.

Taylor, John, 1980, Aggregate Dynamics and Staggered Contracts, Journal of Political Economy $88,1-24$.

Taylor, John B. 1993, Discretion versus Policy Rules in Practice, Carnegie-Rochester Series on Public Policy 39, 195-214.

Whelan, Karl, 2000, A Guide to the Use of Chain-Aggregated NIPA Data. Finance and Economics Discussion Paper no. 2000-35, Washington, D.C.: Board of Governors of the Federal Reserve System. 
Table 1. Welfare under Alternative Policies ${ }^{1}$

\begin{tabular}{|c|c|c|c|c|}
\hline & Durables & $\begin{array}{l}\text { Welfare Loss } \\
\text { Non-durables }\end{array}$ & Total & $\begin{array}{l}\text { Loss } \mathrm{cp} \\
\text { to Opt }\end{array}$ \\
\hline Full Commitment & 2.40 & 1.96 & 4.36 & 0 \\
\hline Output Gap Target & 3.32 & 1.58 & 4.90 & 12.5 \\
\hline Wage-Price Target & 4.16 & 1.14 & 5.30 & 21.6 \\
\hline Inflation Target & 12.2 & 8.6 & 20.8 & 378 \\
\hline Estimated Rule & 4.56 & 1.60 & 6.16 & 41.3 \\
\hline Taylor (true gap) & 4.61 & 3.63 & 8.24 & 89.1 \\
\hline
\end{tabular}

1/ The welfare loss is expressed as a percent of steady state output (multiplied by $10^{-2}$ ). 
Figure 1

\section{Empirical Responses to Monetary Policy Shock: Durables vs. Other GDP}

(sample 1980:1-2000:4, with two standard deviation confidence bands)

Consumer Durables and Residential Investment

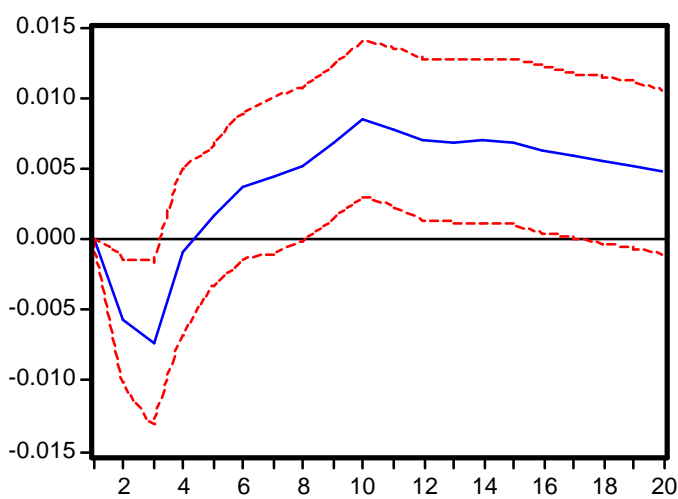

Price Index of Consumer Durables/Residential Investment

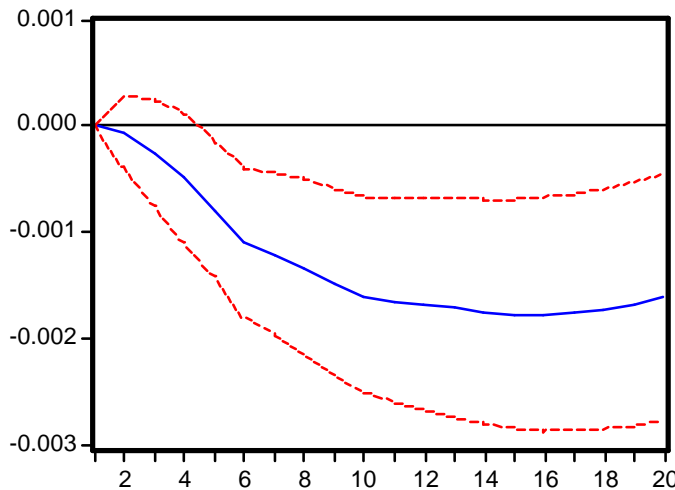

Commodity Price Index

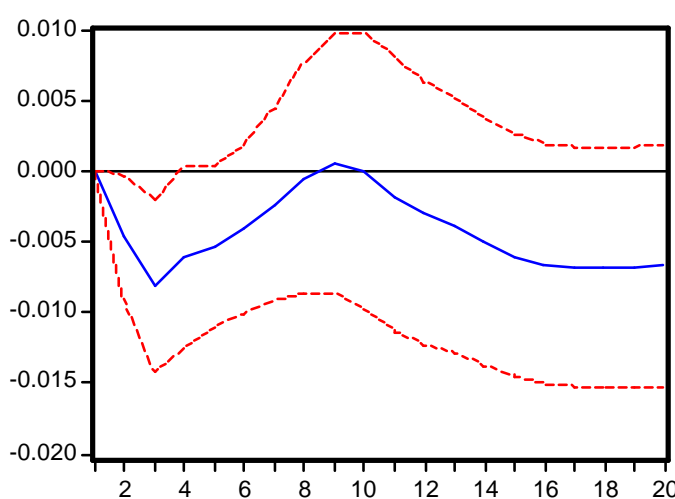

Other GDP Components

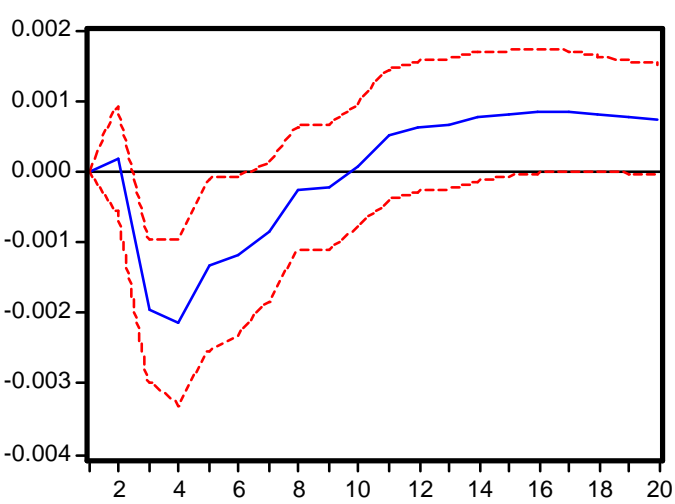

Price Index of Other GDP Components

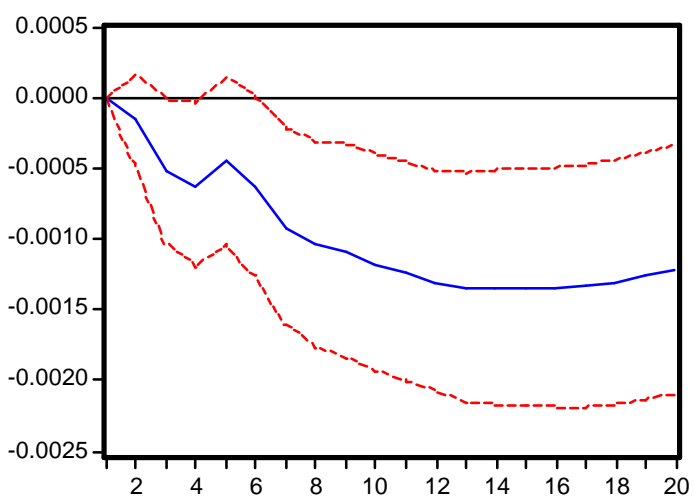

Federal Funds Rate

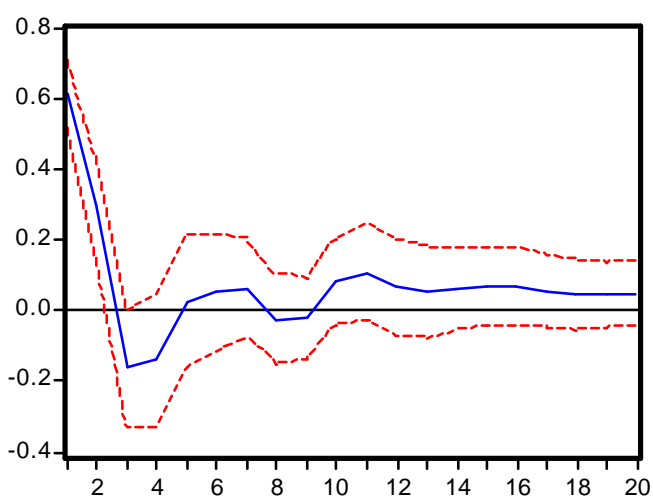


Figure 2. Policy Rule Comparison: Productivity Shock to Nondurables

(One standard deviation innovation)
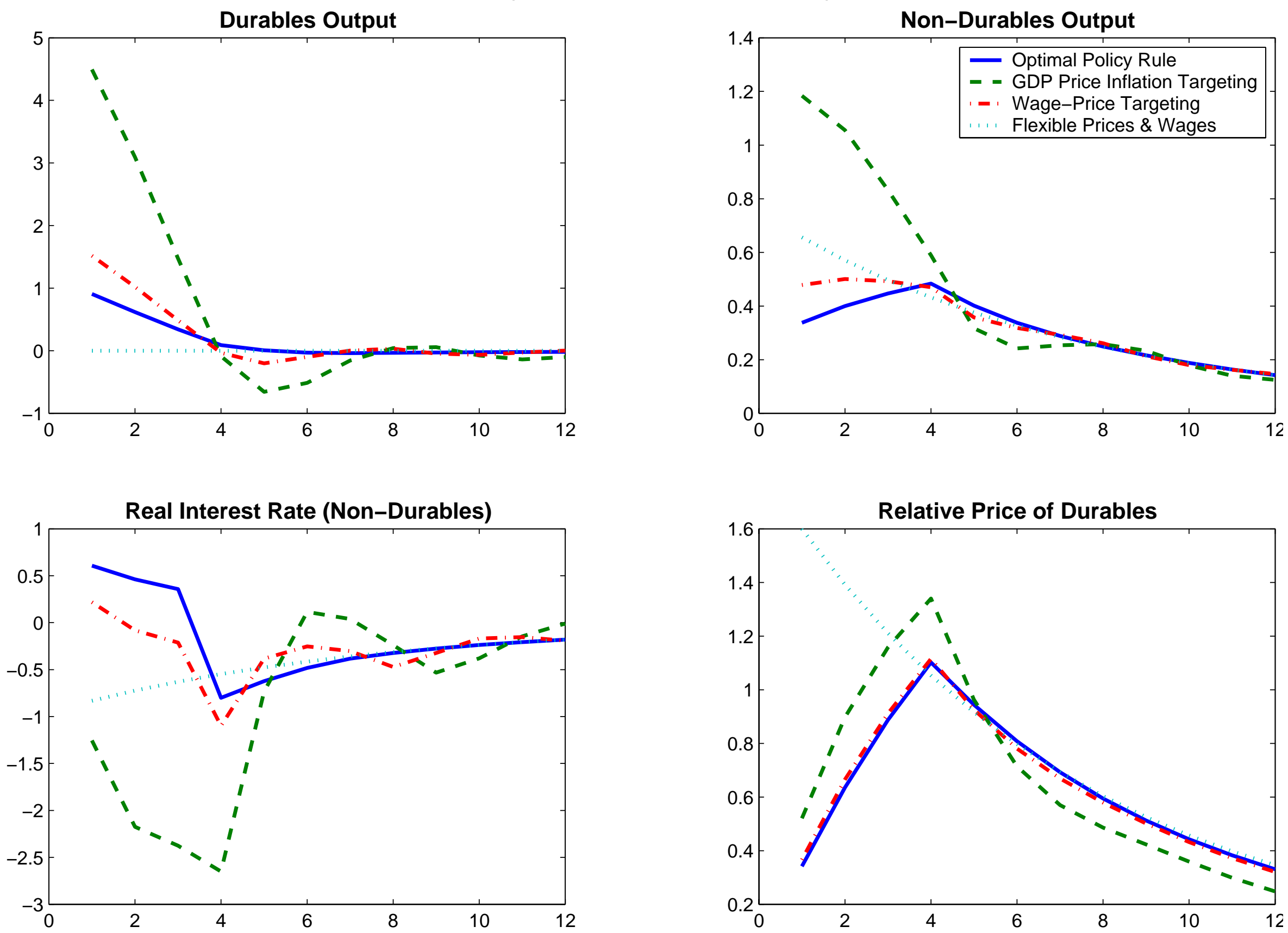
Figure 3. Policy Rule Comparison: Government Spending Shock

(One standard deviation innovation)
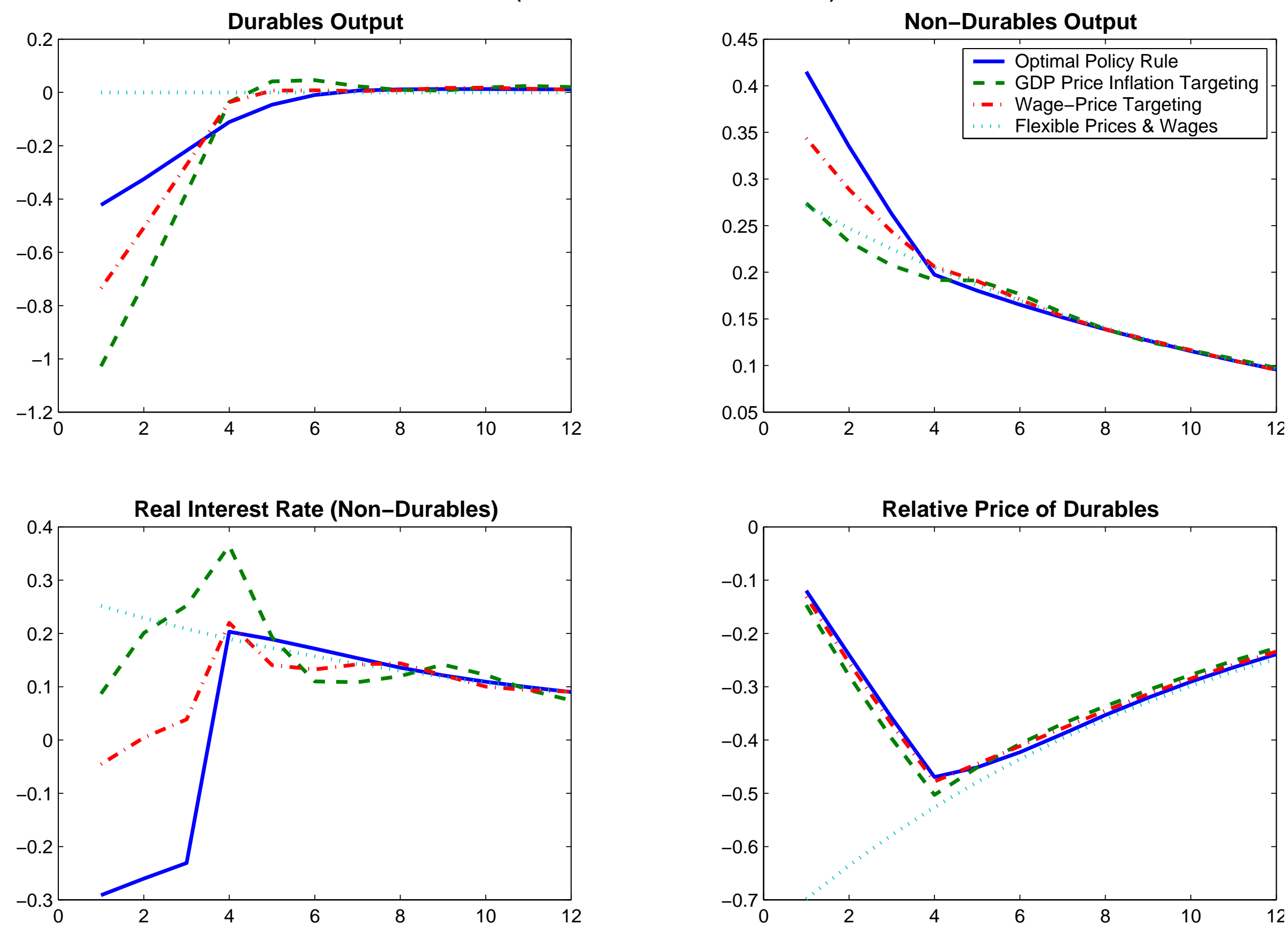